\title{
The Vallipuram Buddha Image "Rediscovered"
}

When, at the end of the $19^{\text {th }}$ century, the Viṣnu kōvil in Vallipuram, in Vatamaracci, in northern İlam (Lankā) was (re)built, a Buddha statue was unearthed close to this temple, 50 yards northeast of it (Ceylon Antiquary 1916-17: 96). It remained in the lumber room of this temple until 1902, when it was set up in Old Park at Yālppāṇam under a bo-tree (Ceylon Antiquary 1916-17: 96-97). In 1906, the Vallipuram Buddha image was presented by Governor Sir Henry Blake to the King of Siam, who was particularly anxious to have it, as it was supposed to be of an archaic type (Ceylon Antiquary 1916-17: 97). This event together with the statue, was forgotten for almost 90 years. All Tamilar and Sinhalese born after 1906 have never seen the Vallipuram Buddha image, provided they have not gone to and found it in Thailand.

The study of the religious significance per se, in its historical setting, of the statue is important. The Vallipuram Buddha image is a typical creation of Amarāvati art, the spread of which documents the spread of Buddhism to İlam, where it exercised a decisive influence on the first period of the development of Buddhist art in the Anurātapuram school. We get then a geographical triangle of a cultural encounter between Amarāvatī, Anurātapuram in its first phase, and Vallipuram. This happened at a time when Buddhism was still not identified as Sinhala Buddhism, but just as Buddhism. The study of the Vallipuram statue is thus a way of transcending or at least suspending for some time polarising ethnic identities, not ethnic identities as such.

We have to mention for the sake of gaining a background to the Buddha image that in an inscription the building of a vihāra is mentioned in an area given as nakadiva (Pāli, Nāgadipa). The Buddha image is probably one of the remains of this vihāra, of which nothing is left today on the sur-

\footnotetext{
* The present author thanks Professor Ci. Patmanātan and Professor Ā Vēluppillai for many comments on this paper.
} 
face. Buddha images usually stand in vihāras. Where there is a Buddha image, there is a viharra. The inscription confirms, then, what we could expect - the Buddha image belongs to a Buddhist institution that was established in Vallipuram. The date of this institution, of which there are no traces on the surface, depends on the date of the inscription.

The inscription is on a gold plate that was found in 1936 beneath the foundation of an ancient structure on the land belonging to the present Viṣu kōvil (Paranavitana 1936: 229), the same area where the Vallipuram Buddha image was found. Exactly when the transformation from a Buddhist vihāra into a Viṣnu kōvil took place is still still an object of research. Usually such gold or copper plates are found in North India inside in stūpas. They were then not meant to be read by the public. They explicitly or implicitly tell about a merit of a donor who had a sacred construction built or maintained, and evidently the donor hoped to get a reward for his generosity in the next lives to come. The documenation of his merits was put on gold or copper that lasts for many existences in the future.

Vallipuram was not a unique Buddhist place in Yālppānam from the first centuries AD. Together, nine places with reference to Buddhism have been identified (Vēluppillai 1990: 15-16). Vallipuram and Kantarōtai belong to the most well-known, or in the present discussion, to the most spectacular ones.

The Vallipuram inscription finally confirms that the historical Nākattivu (Nāgadīpa) is Yālppānam (Jaffna district). There is a mythological reference to the Buddha and the deva Samiddhisumana having resided in Nāgadipa (Mahāvamsa 1958: 1: 52). These references tell us that at least the compilator of the Mahavamsa at the beginning of the fifth century was familiar with "Nāgadipa".

There is a reference to King Devānampiyatatissa (250-210) giving gifts to a Jambukolavihāra in Nāgadīpa (Mahāvamsa 1958: 20, 25). That is a reference that brings us back to the $3^{\text {rd }}$ century BC. We must, however, be very careful with this reference. Devānampiyatissa is depicted by following generations as having taken an Aśokan role. That role implied, and this role was displayed, by the building, restoration and maintaining of Buddhist sacred architecture. It is now difficult to distinguish the Aśoka image of the compilator in the $5^{\text {th }}$ century $A D$, when Nāgadipa certainly was known, from the historical reality. ${ }^{1}$ We will therefore leave this reference out.

\footnotetext{
${ }^{1}$ Cf Dharmadasa 1994: 89, where this Mahāvamisa passage is taken as historical evidence.
} 
There is one of the first historical references of King Mahallanāga (136143) building a vihāra called Sālipabbatam in Nāgadīpa (Mahāvamssa. 1958: 35: 124). There is also a second historical reference of King Kanitthatissaka (167-186) restoring in the Nāgadīpa ghara (Mahâvamsa. 1958: 36: 9). It is not clear what specific building the word ghara, meaning "house", refers to.

A third historical reference is to King Vohārika Tissa (209-231), who is said to have built a pakāra, "wall", in a vihāra called Tissa in Nāgadipaka (Mahâvamsa. 1958: 36: 36). All these three references are clustered in time to the end of the second and beginning of the third century $\mathrm{AD}$. The next reference to Nāgadipa in connection with a Sinhala King falls to the end of the reign of Aggabodhi II, who ruled 604-614. He is said to have given the Uṇnalomaghara temple to the Rājāyatanadhātu and (gave) as well an umbrella for the Āmalacetiya. He also granted to the vihāra there a village for the provision of rice soup (Cūlavamsa 1980: 42: 62-63). After that, Nāgadipa is not mentioned any more by the chronicles. There are then almost 400 years of silence between Voharika Tissa and Aggabodhi II, and this period of silence, and the following period after Aggabodhi II, throughout the mediaeval period may be significant. The chronicles are built on "the merit books" of the Kings. If a King really had made a restoration or built a vihāra in Nāgadīpa, it would have been mentioned in his merit-book and then been taken up by the compilators of the chronicles, and by his retinue or kin in inscriptions referring to him. The silence can be interpreted as an absence of any relation of the Sinhala Kings to the north. The political decision makers of Nāgadipa, who may have been Tamilar, may have turned for protection and cultural exchange towards Dravidian South India instead.

The commentary to the Akitti-Jataka (no. 480$)^{2}$ supports this view of Nāgadipa being related to South India. That reference is especially interesting because it points to a religious intercourse between the South Indian city of Kāvirippūmpatținam (Pāli, Kāveripattana) in Tamilakam (Pāli, Damilarațtham) and Nāgadīpa from about the $4^{\text {th }}$ century AD. The other former references were vague in the positioning of Nāgadipa, but this commentary is quite clear in placing Nāgadipa close to Kāradipa.

In Tamill, we also find the word Nākanātu in, for example the Tamil epic Maṇime èkalai, written by Cāttanār in about the $6^{\text {th }}$ century AD. The heroine

\footnotetext{
${ }^{2}$ Fausbø̆ll 1963: 238: ...anupubbena Damilarațtham patvā Kāvìrapațanasamīpe uyyāne viharanto jhānābhiñnam nibattesi, tatrāpi 'ssa mahālābhasakkāro uppajji. So tam jigucchanto chaḍ̣etvā ākāsena gantvā Nāgadīpasamīpe Kāradīpe otari.
} 
Maṇimēkalai herself visits a shrine called Maṇipallavam in Nākanātu, according to this Tamil Buddhist epic tradition (Cāttanāàr 1981: 160-162). In the $5^{\text {th }}-6^{\text {th }}$ century $\mathrm{AD}$, when both the Mahāvamsa and the Manimezalai were written, there were evidently strong legendary Buddhist traditions about Nākattivu, on the Tamil as well as on the Sinhala side. ${ }^{3}$

The problems the Anurātapuram dynasties had with the north are made evident by looking at the reference to the word uttaradesa, "northern land" in the chronicles. It covers the area north of Anurātapuram, but how far north is not known. It may be a vague reference to the whole of the north of the island. Moggālana III (614-619), who followed Aggabodhi II (Cūlavamsa 1980: 44: 711), fought against Damilas, who had taken possession of Uttaradesa, and several other following Kings did the same (Cūlavamsa 1980: 48, 83-4,95,112;50,14;70,92). The formation of uttraradesa as a Tamil area was a fact in the $6^{\text {th }}$ and $7^{\text {th }}$ century, having been prepared by a cutting of relations from the $3^{\text {rd }}$ and $4^{\text {th }}$ century.

The great value of the Vallipuram inscription is, as pointed out, that this nakadiva is mentioned. It is then an important reference that refers to the very place where the inscription was found. In Pāli in the Mahāuamsa it appears as Nāgadīpa(ka), in Prākṛt it appears as Nākadivva (Nagadīva) and in Tamil as Nākattivu. When we say that Nākattivu is Tamilı, we are of course aware that the word is a Präkṛt loan word that has been Tamilised, but having been Tamilised it has become a Tamil word.

The Vallipuram Buddha image has been "rediscovered". It stands in a central Buddhist vihāra in Bangkok, in Wat Benja, that is known by Western tourists as "the Marble Temple". The present author has visited the place in January 1994 and June-July 1996. The Wat is one of the most visited by tourists in Bangkok - even a commercial bank for money change is placed just outside the entrance - but the Buddha image has no central placement and is therefore not easily observed. The guards and professional tourist guides do not know even that an image called Vallipuram Buddha image is there. In the annexed monastery, not even monks who have spent a life time there, know about this image by this or any other name.

It is placed in a corner on the back side of the Wat well protected from rain, theft and vandalism by an iron curtain. A small wooden board says in

${ }_{3}$ To avoid a missunderstanding: these sources are sources for the conceptualisations of the 5 th century AD. They are not sources for the historical Buddha or for Manimēkalai, who is a poetic creation. 
Thai and English that this image depicts the Buddha dispelling evil from the island of Ceylon. No reference to Vallipuram is made. A yellow transparent schal has been wrapped around the statue and at its feet are placed pots with incense. The corner is made into a place of veneration, but it cannot compete with the other statues in the Wat that are placed strategically along the main walk of tourists and venerators.

A replica has been made and was in January 1994 ready to be sent to Colombo on the request of the Sinhala authorities. ${ }^{4}$

It is a life-size statue in limestone (Paranavitana 1983: 79). It was said to weigh half a ton (Ceylon Antiquary 1916-17: plate 10, 2). The Buddha is depicted as standing (see pictures 1-2). The sculpture's right hand seems to have been replaced by a new hand and its left-hand fingers seem to have been repaired. There exists a photo of the Vallipuram image taken when it was still standing on a low platform of stone under the bo-tree in the Old Park of Yālppānam. The photo shows that at this stage the whole right arm was broken away up to the shoulders and that the whole left hand holding the robe was missing (Ceylon Antiquary 1916-17: plate 10, 2). All this has been substituted today by artists in lime, and the substitutes are recognisable on coloured photos. The present author's interpretation of the mudra ${ }^{5}$ of the right hand is therefore a conjecture, but a reasonable one (see below). The Buddha is not surrounded by any of the Buddha's followers. Let us now give an impressionistic description of this statue.

The usnișa ${ }^{6}$ is very small and low on top. The hair is curled in small curls that are indicated as small dots in relief. It is difficult to make out in which direction the curls are going. The face is round and fleshy, like the whole of the body. The eyes are rather crudely formed in almond shape. The front is high browed. The eyebrows are high-flown. There is no ürna ${ }^{7}$ visible now and it seems there has never been one. No iris is visible, therefore giving the impression of a blind man. The nose is big and broad and the lips are thick. There is an indication of a smile. The ears are much prolonged: they reach down to the lower part of the neck and almost the shoulder. They end up in knotty lobes. The neck is that of a fat man with indications of a triple chin.

There is no antaravâsaka ${ }^{8}$ visible under the uttarāsangha ${ }^{9}$ that falls in heavy, loose pleats. It is not possible any more to determine if the original

\footnotetext{
${ }^{4}$ Oral communication from the Department of Fine Arts, Bangkok, January 21, 1994.

5 "gesture (with the hand)"

6 "turban", used here in the sense of wisdom-pump.

7 "lock", used here in the sense of point between the eyes.

" "lower garment"
} 
right hand mudrā is abhaya. ${ }^{10}$ The hand is replaced. The new hand is badly done and the "restorers" consciously tried to imitate āśisa mudrā." That is a variant form of the abhaya mudrā, but it is known to be typical of Sinhalese Buddhist iconography as we know it from the Avukana statue of the $5^{\text {th }}$ to $7^{\text {th }}$ century. Evidently the restorers of today tried to give the statue a Sinhala look by making the hand into a assissa mudrā, knowing that this was part of the (later development of the) Anuratapuram school of art. This is the first indication of an ethnic-political Sinhala-Buddhist interpretation and handling of the statue. To come to the original, we have just to disregard this recent "restoration" and stick to the paradigm that these standing Buddhas from Amarāvatī have the common abhaya mudrā. None of them has an āsiisa mudrā.

We should of course not disregard this Sinhala "restoration" as an indication of the political exploitation of that statue. It is paralleled with the "restoration" of the word in the inscription so as to fit Sinhale interests.

In the inscription we find the word isigiraya. There is no controversy about the reading of the Brāhmì letters as isigiraya, but to fit a Sinhala interpretation, K.N.O. Dharmadasa, Professor of Sinhala at Peradeniya University, who represents an extension of the Paranavitana school (see below), following his teacher S Paranavitana faithfully, revives his reading isigir-i-ya. ${ }^{12}$ That small, but important and seemingly arbitrary change of a vowel from a to $\mathbf{i}$ makes it possible for Dharmadasa to interpret the word in a Sinhala way as isi-giri, "the rock of the rṣi"! (Dharmadasa 1994: 8890) This is what we could call a "Sinhala interpretation". It excludes the possibility of making a Tamil reference. If we take the reading as it is there is no controversy about it - we find a Tamil name Isiki, and there is rayan. In Prākrtised form they may appear as isigiraya. The *isi-giri is an outcome of ethnically based wishful thinking, like the "restoration" of the Buddha hand into an āśisa mudrā (see above).

The left hand of the Buddha holds up the fall of the uttarasangha that covers even the feet except for the toes that are indicated. The absence of a penis is indicated by the fall of the uttarassangha along the front side. He

\footnotetext{
9 "upper garment"

10 "gesture of fearlessness"

11 "gesture of blessing"

${ }^{12}$ Paranavitana in one footnote said that isigiraya stands for Sanskrit Rșikarāja and in another footnote that it stands for Sanskrit Rșigirika or Isigirika. See Paranavitana 1936: 237, note 6; Paranavitana 1983: 81 , note 8 . No explanation for the change of vowel is given.
} 
has a narrow waist, but broad shoulders that give an athletic look, and large hips that associate with a woman.

We may find his look rather "rustic", but the parallels to this statue were royal statues of the Satavāhanas dynasty in Andhra and the following İkșāku dynasty. The former ruled between ca $230 \mathrm{BC}$. to the $3^{\text {rd }}$ century AD. followed by the İkșvāku in Andhradeśa proper. It is during their rule in the second half of the $3^{\text {rd }}$ century AD. that we hear in inscriptions about a Sỉhala vihāra for the accommodation (Vogel 1929-30: 22), - not of Sinhalese monks, - but for monks from the island called Sinhala. This information then perfectly fits the time and place of establishing a Buddha statue in Vallipuram inspired by Andhra art.

We should of course not think of the Vallipuram of today as being a centre for Tamil Vaisnavism lying rather isolated in the hot dunes of Vațamaracci (Ragupathy 1987: 83-85). Vallipuram has very rich archaeological remains that point to early settlement. It was probably an emporion in the first centuries AD. It is part of a route for traders and pilgrims that went along the Eastern coast of Ilam. Vallipuram is also close to the Nàkapattinam coast, with easy access from the Andhra coast.

The stylistic place of origin of the Vallipuram image is quite clear: the Dravidian area of Amarāvatī that together with finds from Bhattiprolu, Jaggayyepeta, Ghanataśālā, Nagarjūnikonda and Golī was one creative centre in Andhra for Buddhist art from about $2^{\text {nd }}$ century BC. to the $3^{\text {rd }}$ century AD. under the Satavāhanas and İkṣvākus (Coomarswamy 1980; Boisselier et al. 1978; Härtel 1971).

The Buddha image appears there only from the end of the $2^{\text {nd }}$ century AD. replacing symbols for the Buddha, and lasts throughout the $3^{\text {rd }}$ century. From already dated stones with which we compare this Vallipuram statue, we can conclude that it falls in the period $3^{\text {ra }}-4^{\text {th }}$ century AD. During that period, the typical Amarāvati-Buddha sculpture developed. It was inspired by the sculpture of Gāndhāra and Mathurā and spread to South India, İlam and Southeast Asia, but not before the $4^{\text {th }}$ century AD.

The returning attributes for this standing Buddha in stone are: he is more than life size; he holds the end of the uttarāsangha in the left hand; the right hand is lifted to abhaya mudrā; the curls of the hair are flat; the face is round; the uṣniṣa is low and small and the uttaräsangha is falling in pleats. This is the model for the standing Amarāvatī Buddha statue (see figures 1-3).

The expression "Anurātapuram school" seems to indicate that there was a Sinhala school in Anurātapuram that was formative for the development 
of the Buddha images. So, one expects to hear that the Vallipuram Buddha image is influenced by the Anurātapuram school.

What, however, is the "Anurātapuram school"? It falls into two phases, the first up to Dhätusena in $459 \mathrm{AD}$. and the second to the abandonment of Anurātapuram in the $10^{\text {th }}$ century $\mathrm{AD}$. From the first period very little is left regarding Buddha images, and what is left follows the ideal of Amarāvatī. The oldest-known Buddha image in the Sinhala area from this period is from Maha Illupallama in the district of Anurātapuram. It is six feet high, of white marble probably imported from the Vengi region in Andhra. It is an example of Amarāvatī art.

Another old Buddha-image is from Metavacciya dated to the $4^{\text {th }}$ century AD., a bronze statue of $46 \mathrm{~cm}$. It is reminiscent of the Amarāvati school, both in the attitude and in the way the robe is adjusted (Boisselier et al. 1978: 141). We do not find the âsisa mudrā at this stage. It belongs to the Anurātapuram school's second phase, as documented by the Avukana statue.

It is then only in the second phase that the Anuratapuram school develops specific features for what we can call Anurātapuram or Sinhala Buddhism. In the first phase this school was just receiving influences, like Tamilakam ${ }^{13}$ and Nākattivvu in northern İlam. In this first phase it was the heir and descendant of the Amarāvatī school like South India, Nākattīvu and, not to forget, Southeast Asia (Boisselier et al: 140-167). These statues, one of which is the Vallipuram statue, we all date stylistically to about about $3^{\text {rd }}-4^{\text {th }}$ century AD. Their setting up was hardly possible before the $4^{\text {th }}$ century $\mathrm{AD}$. We have to see the Vallipuram image as a result of a wave of Buddhist sculpture initiated in Amarāvatī. The Buddhist culture to which this statue belongs is Dravidian and South Indian, more precisely Andhra. We get then, as mentioned above, a geographical triangle of a cultural encounter between Amarāvatī, Anurātapuram in its first phase, and Vallipuram. Only in the second phase of the development of Buddhist art in Anurätapuram was this belonging together of Buddhists from South India and İlam abandoned and replaced in Anurātapuram by a Sinhala Buddhist art.

Why is the Buddha image so important? The image is important for two reasons. One is its historical importance, indicating a free cultural exchange beyond ethnic conflicts in the triangle Amarāvatī-Anurātapuram-

${ }^{13}$ The area from Vēnkatam to Kaniyakumari. 


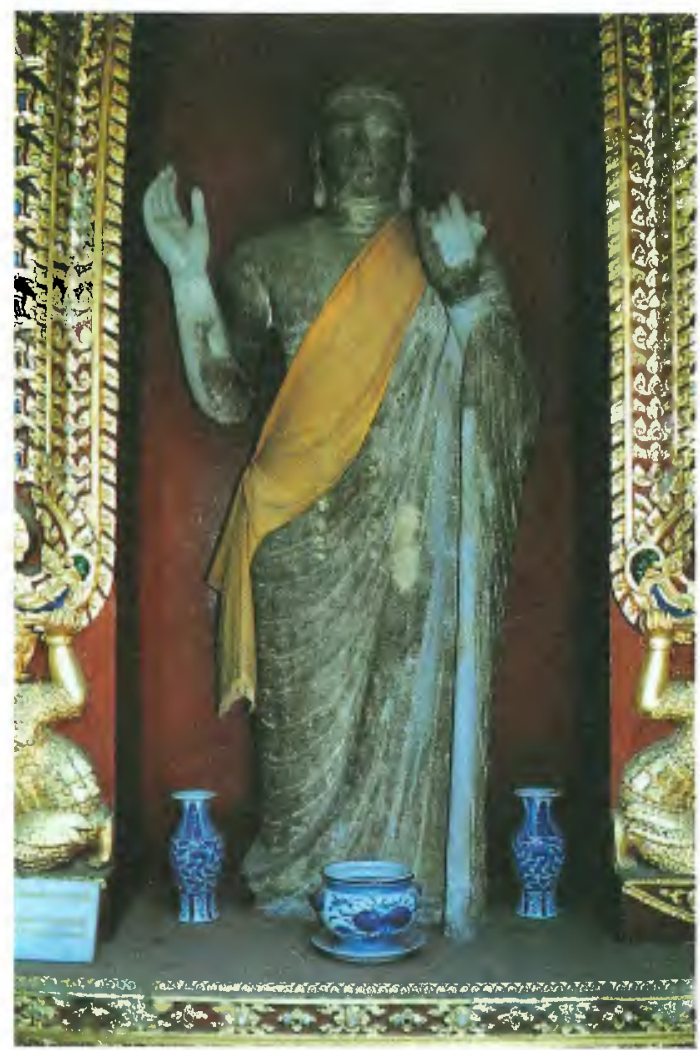

Fig. 1. The Vallipuram Buddha image from Wat Benja in Bangkok. Photo: Peter Schalk, January 1994.

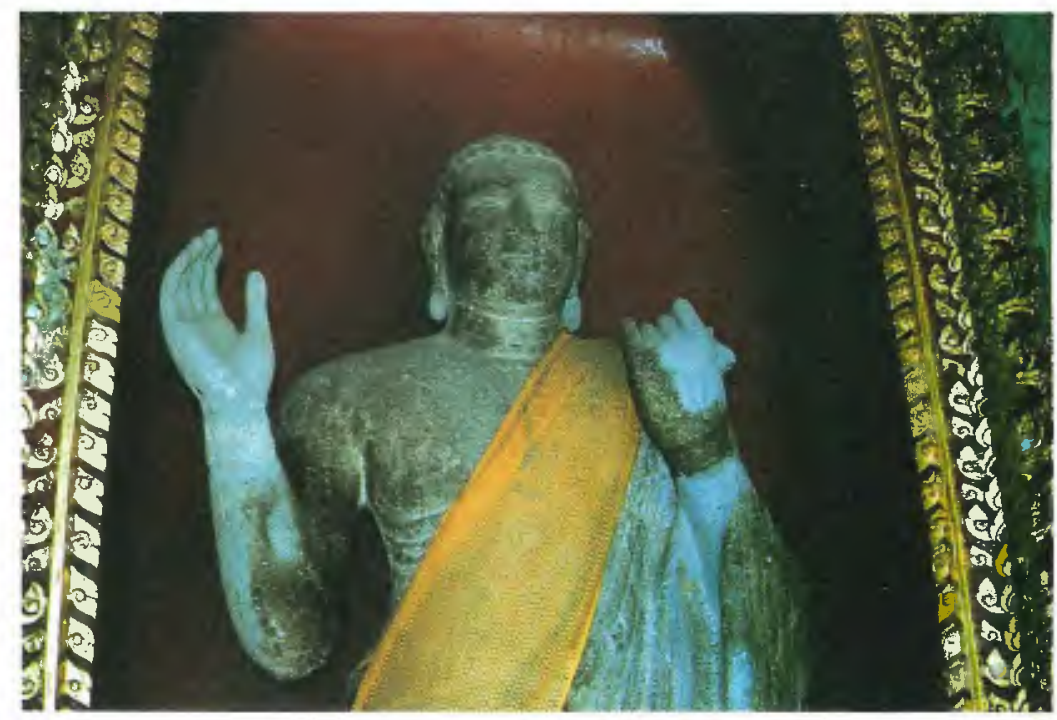

Fig. 2. Close-up of the same picture. Photo: Peter Schalk. 


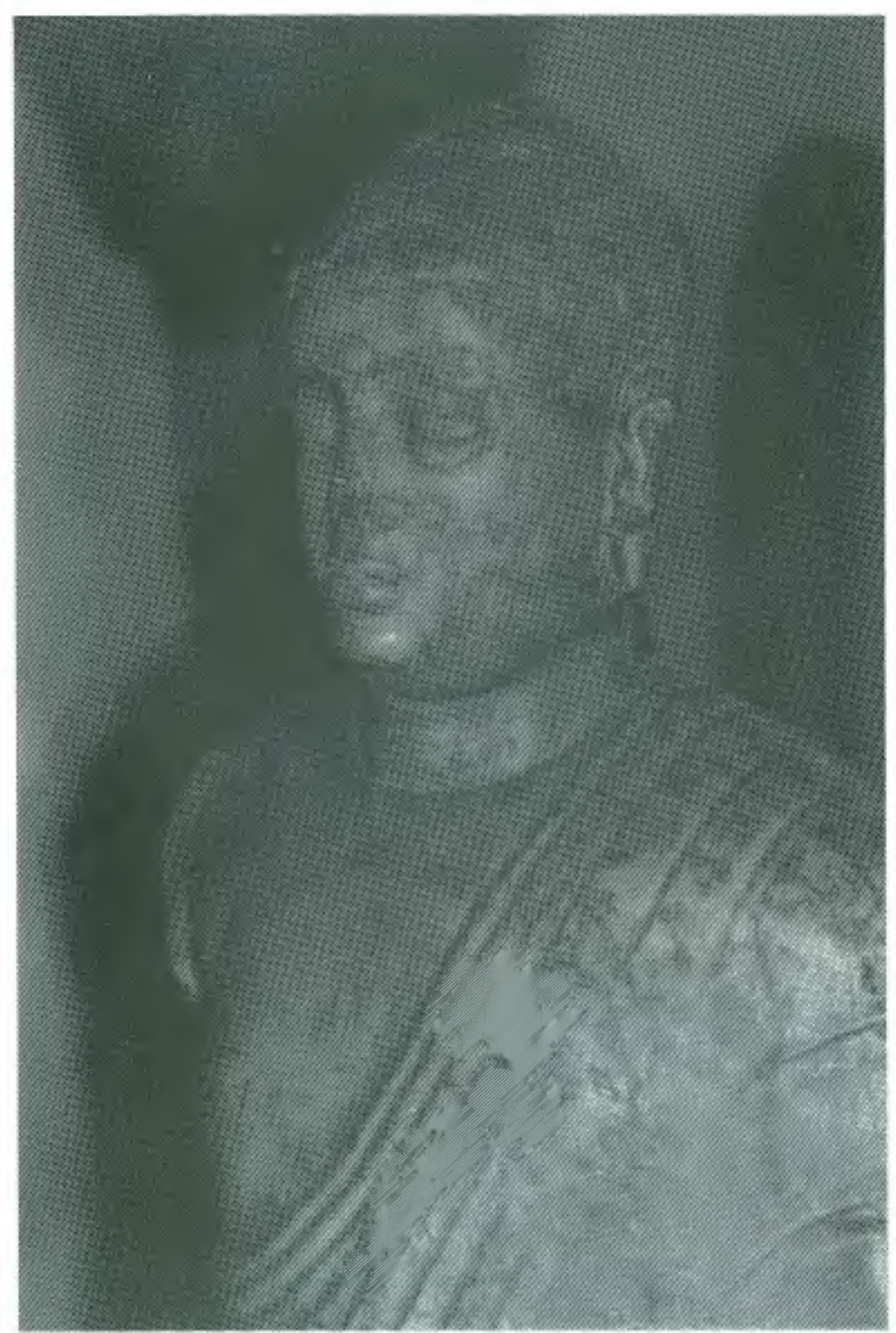

Fig. 3. The Buddha holds the end of the uttarasangha in the left; the right hand is lift to abhayamudrā here missing); the curls of the hair are flat; the face is round; the ușnisa is low and small and the uttarāsangh a is falling in pleats. This is the model for the standing Amarāvati Buddha statue. By courtesy of the Director, Madras Museum. Photo: Peter Schalk, January 1994. 
Vallipuram, and the other is its present political importance as an object of exploitation in the ongoing ethnic conflict on the island.

We have already elaborated on the first reason above. Let us elaborate now on the second reason here that has been indicated above by the sculptural and verbal "restorations" of our sources by Sinhala enthusiasts. The area in Yālppānam district is now 100\% Tamil. Tamilar are today related either to Saivism or to Christianity or to Islam, but not to Buddhism. In the past, however, in precolonial İlam, there were Tamil Buddhists, but this has not been emphasised in the historical writings by Sinhalese and Tamils. ${ }^{14}$ So, the finding of Buddhist places in Tamil areas today creates a tension in the minds of both Sinhalese and Tamilar, because Tamil Buddhism, like Mahāyāna, has today no recognition in the Lankan (Sinhala) Buddhist sangha. Many Tamilar also - not Tamil scholars of course - are unaware of Tamil Buddhism because their concepts of Buddhism were given to them by Sinhala Buddhists. Some Sinhalese scholars stipulate that there were Sinhala Buddhist settlements in early history that were overpowered by Tamil settlers in the mediaeval ages. Even a Tamil scholar, a professor of history, has taken this stand, and this is of course noticed and fully exploited by the Sinhala intelligentsia. ${ }^{15}$

An often quoted paper in the Journal of the Royal Asiatic Society by the Sinhala historian P.E Pieris from 1917 explicitly connected finds of Buddhism in the North with "Sinhala supremacy", "Sinhala power" and "Sinhala occupation" (Pieris 1917: 12, 14). This paper gave a special communal edge to the start of archaeological work in the north. One of the places discussed was Vallipuram (Pieris 1917: 17). He and his followers just could not imagine that there was a Buddhist tradition transmitted by Tamilar in the north.

In 1983, the year of the Tamil pogroms in Colombo, Cyril Mathew, the Minister of Industries and Scientific Affairs and "President of the Congress of Buddhist Associations of State Corporations and the President of the Foundation for the Restoration and Protection of Buddhist Shrines in Sri Lanka", published a remarkable book that was distributed worldwide and that he sent to UNESCO in Paris. He had written it in English in cooperation with M.H. Sirisoma, Assistant Commissioner of Archaeology

\footnotetext{
${ }^{14}$ An exception on the Sinhala side is Gunawardana 1979: 47-48, 202-203. On the Tamil side see Veluppi!llai forthc.

${ }^{15}$ Hettiaratchi 1988: 140: "It is to be mentioned that though at present the majority of the people settled in the above province are Tamils, $\mathrm{K}$. Indrapala has rightly pointed out that Sinhalese constituted the main population there till about the thirteenth century."
} 
from the State Department of Archaeology. In this book was a map that allegedly showed Sinhala Buddhist places. They were now "unlawfully" occupied (Mathew 1983). ${ }^{16}$ One of them was Vallipuram.

In between Pieris and Sirisoma came the historian, epigraphist and archaeologist S. Paranavitana ( $†$ 1972), who in an article from 1936 published in Epigraphia Zeylanica - see below - took up the political trend in archaeology initiated by Pieris. He quoted Pieris. He used the Vallipuram inscription and Buddha image to rationalise Sinhala claims on Tamil areas in the north. So, there is a continuous tradition of a politicised Buddhist historiography among academics, from Pieris via Paranavitana to Sirisoma, and, if we want to go further back, to the chronicles themselves that have Buddhist Sinhala nationalism as a main theme. Today this tradition is contradicted and opposed by several Sinhala historians, but still it is a force of long-range character. There are evident ideological survivals of this ethnically based historiography in departments of history, archaeology and Sinhala.

It is this way of Sinhala "hegemonistic" thinking, being so characteristic of Sinhala modern national politics, according to an official spokesman of the Lankan Government (Jayaweera 1991), that gives the Vallipuram image such importance. This spokesman, who served as Ambassador in Stockholm till October 1994 and speaks from his experiences as Government Agent in Yālppānam in the 1960s, wrote in 1991 that "throughout most of its recent history, Sri Lanka has been a hegemonistic society" (Jayaweera 1991: 33). We have elsewhere called this thinking "dharmacratic" (Schalk 1990b: 354-359). Seeing now the possibility of getting at least a replica back from Thailand of the Vallipuram image, this thinking gets mobilised and enforced; it gets a visible object through which "hegemonistic" or "dharmacratic" feelings can be mobilised and channeled.

The late President Premadasa, who was killed on 1 May 1993, was an ardent Sinhala Buddhist who made himself Minister of the State Department of Buddhism. He did not speak as a historian who tries to find out how things really were, but as a politician with vested interests. He knew that he could exploit politically the Vallipuram Buddha image to rationalise the concept of unity of the island and sovereignty of the Sinhala Gov-

\footnotetext{
${ }^{16}$ The Preface in Mathew 1983 was signed on 20 July 1983, the day when the antiTamil pogroms started. In the "Acknowledgments" after p. 167, he acknowledges the contribution by Sirisoma for having collated the material and taken a keen personal interest in the publication of this work. Mathew was sacked from the Government in 1985 for his anti-Tamil campaigns that upset foreign diplomats.
} 
ernments (Schalk 1988a; Schalk 1988b: 55-87; Tambiah 1992). ${ }^{17}$ We have to recall here G Obeyeskera's old observation from 1970 that Buddha images in public places are tokens of the idea of a Buddhist nation (Obeyesekere 1970: 50-51). Premadasa exploited this fact.

In January and February 1991, Government newspapers in İlam suddenly flashed the news that the Vallipuram Buddha image may be rediscovered in Thailand and transported back to Lanka (The Sunday Observer (Colombo), January 20, 1991). Another article in the media tells the public that the Vallipuram Buddha image has been found and that the President ( $R$ Premadasa) has made an appeal to King Bhumibol of Thailand to give back the image to Lankā. The President is reported to have said that the Vallipuram statue is of great historical and religious significance to Lankan Buddhists (Daily News 1991: February 2).

One further important point in the study of the Buddha image is that the statue is combined with the finding of a separate inscription on a gold plate that makes it possible to say something about the linguistic identity of the culture, i. e. about the historical setting to which this statue belonged. In modern terms, we would say that the inscription makes it possible to label the ethnic identity of the area in question in the first centuries $\mathrm{AD}$. There are no other Buddhist inscriptions from that time - the first centuries $\mathrm{AD}$. - from Yālppānam ${ }^{18}$, and therefore this inscription is very important. This inscription then becomes highly interesting for politicians for political exploitation. $^{19}$

\footnotetext{
${ }^{17}$ For a review of Tambiah 1992 see Schalk 1993.

${ }^{18}$ There is of course the Ānaikkōttai seal on a metal piece dated to the 2nd century BC. The reading of its three syllables has been amended to kōvētan and kōvēntanutaiya, being allegedly a Tamil word. If the reading is correct, then we can document the existence of Tamil in the north alreday for the $3 \mathbf{r d}$ and 2 nd century BC. The reading and dating, however, have not yet been comfirmed. See Ragupathy 1987: 200-204; Vēluppi!llai 1990: 13.

${ }^{19}$ For President Premadasa's manipulations with the Vallipuram inscription see Anon. 1994, that praises him for being a great man: “The man's greatness surpasses his weaknesses". To manipulate is not ugly if it is done in the national interest, is the point of the article. To his "greatness" also belongs his ability to manipulate archaeology. The article says: "Premadasa was a brilliant stage manager. He could create, orchestrate and if necessary even manipulate situations to make himself look the winner, emerge unrivalled and the best. When Premadasa obtained with great persuasion a copy of the Vallipuram gold plate from the scholar bhikkhu Ven. Walpola Rahula, which many thought was stolen, he was slow to make it public. - The Vallipuram gold plate unearthed near a Hindu temple in Point Pedro[sic] is an undisputed [sic] piece of evidence which establishes that during the pre-Christian period the Sinhalese lived and governed Jaffna and were subject to the ruler in Anuradhapura. Without making it public,
} 
Regarding the language of the inscription, we have theoretically four alternatives to play with: Sinhala Präkrt, ${ }^{20}$ Prākrt with a Tamil substratum (Vēluppillaiai 1990: 10-42) ${ }^{21}$, Prākrtised Tamil ${ }^{22}$ and Paiśāci-Prākṛt. ${ }^{23}$ The problem is that the inscription is so short, being isolated from a bigger tex-

he invited a number of scholars and associates to write about the gold plate, its contents and its significance for today. Only when the people realised its value and started discussing and debating its relevance to the demand for a separate homeland did he make it public. He orchestrated the public to challenge those who were unreasonably speaking of a northeast which has been lived in by the Tamils and therefore claimed a separate Tamil country.- After having planted the seeds, Premadasa sat back watching the debate. That was the Premadasa style of operation."

${ }^{20} \mathrm{~S}$. Paranavitana states that the language is old Sinhalese conforming, in general, to the grammatical standards followed in other documents of that period. S. Paranavitana 1936: 230.

${ }^{21} \bar{A}$. Vēluppillaji opens up a new perspective. He starts from the fact that Prākṛt was commonly used in South Asia and that Präkrit then was used also by Tamils as reflected in the Vallipuram inscription. Following S Konnow, he finds some Tamil influence. The existence of this Tamil influence tallies with our knowledge about a wider Tamil or Dravidian substratum of these inseriptions in writing and language. The use of Prākrt then is no indication of a new element introduced by Sinhala Buddhists, according to Vèluppillai.

${ }^{22}$ Irã. Nāgacāmi is explicit in saying that the inscription appears in such a way that Präkrt and Tamil have been blended. He compares it to the blending (of Indo-Ariyan and Tamil) that appears in the streets of Madras when somebody says: istukinẹ putțan instead of iluttukkonțu pōyvittāṇ. See Nāgacāmi 1994: 220-222.

${ }^{23}$ This alternative is proposed by the present author as an alternative to be examined, by no means to be finalised. There are at least two Präkrt languages which have the phonetical indications of a Tamil influence, the shift in some cases from medial forms to tenues, as we can see in this short text. These two languages are Paisāci and Cūlikapaišāci, which are not always distinguished. The writing of Nāka- instead of Nāga- in Nākattivu, and -guka instead of -guha in Piyagukatisa need not to be a Tamil influence, but could be (Cūlikā) Paisāai writing. Paisāaci, when discovered by Western linguists in the 19th century, was defined as a form of Aryan speech which is formed in the mouth of Dravidians when they try to speak Aryan. This falls in line with Veluppi!lai's theory. Now, we know that it has no Dravidian influence, but it looks no doubt like a typical Dravidian phonetic development. The finding of the Amaravati statue in Vallipuram and the Amarävati related writing on the Vallipuram gold sheet, makes it really tempting to put also the language of the Vallipuram inscription together with the Prākrt inscriptions from Amarāvati, which are defined by some scholars as Paisāci, and so we get a large corpus which makes a linguistic analysis possible. It may support the view that the Vallipuram inscription has nothing to do with "Old Sinhala". This linguistic analysis gets confirmation in a late Buddhist tradition from the 8th century, according to which the Sthavira, to whom we normally ascribe the use of Pāli, used Paisāci. See Hinüber 1986: 70. 
tual codex and context, that it is possible to argue for all four. The limitation of the material makes much possible, but also little credible.

The common denominator of all four is the word "Prākrt". ${ }^{24}$ This is a family name of a number of middle Indian languages, and so it poses the problem which Prākrt language is meant. The first and fourth alternative, Sinhala Prākṛt and Paiśāci Prākṛt are quite precise, but being precise they become overdetermined due to the shortness of the text; it is just not enough to test such precise alternatives.

The historical implication of each alternative of linguistic culture is also clear. If the language is Sinhala Prākrt, then references in the inscription itself refer to a Sinhala Buddhist tradition with its centre in Anurātapuram. If the language is Prākrt with a Tamil substratum, Prakritisised Tamil or Paiśāci, we can relate it to the Dravidian area where we find all three alternatives. The point is that in modern Sinhala ethnic consciousness the theory of a Tamil substratum in Sinhala Prākrt or in "old Sinhala", or the existence of Tamil cognates to Sinhala terms, is rejected. The change from medial forms to tenues, for example in the change from nāga to nāka, is not recognised as being due to an influence from Tamil, but is seen even by a professional linguist as a development within the Sinhala languge. Sinhala language purism is part of ethnic thinking, and therefore,

\footnotetext{
${ }^{24}$ The differences start already with the classification of the language. Paranavitana's classification "old Sinhala" that he uses together with Sinhala Prākrrt is not a technical linguistic term, but appeals to a popular understanding that the original language of the island was Sinhala, and that the Vallipuram inseription is part of this language. A more technical way of speaking of the origin of Sinhala would be Sinhala Prākrtt. There are many Präkrt-languages that were used as vernaculars and in writing before Sanskrit was widely used. All Prākṇt languages are Indo-Aryan languages. In a historical classifaction of these languges they are together with Pali classified as middle Indian languages preceded by Vedic Sanskrit and classical Sanskrit and succeeded by modern vernaculars like Hindi, Bengali, modern Sinhala, etc. The kind of Prākrt that constitutes "old Sinhala", i.e. the Prākrt out of which modern Sinhala should arise, has its origin in Northern India. Sinhhala Prākrt is an immigrated language in the island as much as Tamil. In this process of immigration and settling, Sinhala Prākrțt was exposed to influences from another middle Indian language, from Pāli, and from Sanskrit. Pāli was an artifical language constructed also from a Northindian Prākṛt, but limited in its use for transmitting Buddhist traditions. Sanskrit was used for the transmission of learned culture. Sinhala Prākrt was also exposed to the influence of Tamil so much so that only in the 20 th century linguists could convincingly show that Sinhala was not a Dravidian language, but that it was an Indo-Aryan language. The substratum theory has good arguments. See Vēluppiḷ!ai 1979-80: 6-19; Vēluppillai 1980; Karunaratne, 1984: 43; Elizarenkova 1972: 126-137.
} 
when saying that a document is written in "old Sinhala", it excludes any relation to the Tamil language, to Tamilar we could say.

Although there is little controversy about the reading of the text, the interpretation that is applied already in the translation differs widely. From these different translations, different historical conclusions are drawn relating to the ethnic identity of the Vallipuram area. The identification of the language is therefore from a present point of interest important. It is regarded as basic to the determination ethnic identity of the image and the inscription. This determination of the ethnic identity is then projected backwards into history as if the present conflict was already then a daily phenomenon. The determination is open for political exploitation of the Buddha image and of the inscription. Especially in the present fatal ethnic conflict, when the historical outlook is determined by a strong ethnic interest, the constructed and imagined ideal past is made a norm for the future. If the past was Sinhala, it rationalises Sinhala settlements in the present Tamil areas. If the past was Tamil, it rationalises an autonomous Tamil administration with a transmission of Buddhism in Tamil. The Vallipuram image and the Vallipuram inscription have been used in this kind of "interested" historical writing. These two belong to "the hottest" artefacts in South Indian history. To "touch" them is risky. A "wrong" word provokes intensive feelings. ${ }^{25}$

The dominating interpretation has of course been delivered by the dominating ethnic group, the Sinhalese, whose intellectuals are representatives of the first alternative, that the language is Sinhala Prākrtt or "old Sinhala". ${ }^{26}$ We should of course test all four alternatives in the same critical

\footnotetext{
${ }^{25}$ See the following controversy: Schalk 1994a; Silva 1994; Schalk 1994b; Schalk 1994c; Dharmadasa 1994; Schalk 1994d.

${ }^{26}$ Paranavitana himself said in 1936 that Vațamaracci, where Vallipuram is situated, is now densely peopled by Saiva Tamils. Remains of the Sinhalese Buddhist civilisation have been found which flourished in this extreme northern district of Ceylon during earlier periods of history, as it did in the rest of the island. His conclusions of his analysis of the Vallipuram Gold Plate are worth quoting because they have influenced the intellectual debate for decades. Paranavitana wrote: "This inscription [on the Vallipuram Gold Plate] also proves that Nāgadipa was governed in the second century by a minister of the Anurädhapura king, that Sinhalese was the prevailing language, and that Buddhist shrines were being built there. In such references as there are to Nāgadīpa in the chronicles, as well as in other Pāli writings of Ceylon, there is no indication that in early times this differed, as it does to-day, from the rest of the island in the nationality of its inhabitants and their language and religion. In fact there are indications that the extreme north of the island played a very important part in the political, religious, and cultural history of the ancient Sinhalese people. This continued so
} 
way. We must be aware that different classificatory interpretations are possible of the same word and that the inscription, being part of a linguistic encounter-area (Tamil, differents Prākṛts), has differerent language layers. The language purism of present Sinhala consciousness with its rigid borders between the languages is unhistorical.

What is said about Sinhala consciousness is invertedly valid for Tamil consciousness that has been constructed and projected as a reaction to the former. Tamil consciousness has also at present within itself a trend of language purism that "cleans up" everything that reminds of the "Aryan" influence, and by "Aryan" is not only meant the Aryan languages, but also Buddhism. Leading Sinhala scholars like Paranavitana had taught the Tamilar that Buddhism in Lankā is Sinhala Buddhism, and the Tamilar believed him. He is one of the persons who with the authority of one of the most outstanding scholars in Sinhala academic traditions linked Buddhism to Sinhala culture. From that stand, statements about the existence of "Tamil Buddhism" on the island seem to be absurd.

There is also among Tamil scholars a reaction to the Sinhala drawing of borders. This reaction is expressed by emphasising the Tamil substratum theory (A. Velluppillai) and the existence of Tamil cognates (Po. Ragupati) being models for Sinhala words. These theories, independent of their truth value, can in the present situation of segregation be seen as a request for recognition within Lankan society. They want to modify an exclusive Sinhala consciousness by pointing out that there has been a relation between Sinhala and Tamil since historical times.

Tamil consciousness can of course also become exclusive in separatist ideologies with a rigid linguistic Tamil purism as a base. These ideologies depict Buddhism either as a stranger in İlattamilttēcam or they provoke the making of a distinction along ethnic lines between Sinhala and Tamil Buddhism.

We have to notice, then, that there is a Sinhala and a Tamil approach in the formation of interpretations. These approaches consist of a pre-

right down to the end of the Polonnaruva period, though it is likely that the proportion of the Tamil element in the population was greater here than in the rest of the island and gradually went on increasing." (Paranavitana 1983: 80). In the same paper on the Vallipuram inscription he summarises: "It is hardly necessary to say that at the date of this inscription and up to the thirteenth century, Nāgadipa was as much Sinhalese territory as any other part of the island".(Paranavitana 1983: 80). We shall disregard here the political aspects of this historical research and focus only on the descriptive historical statements. What concerns us really is if the factual statement that the inscription contains "Sinhalese" is correct. 
knowledge that is confirmed in the interpretation of the inscription. Usually the inscription is used to confirm preconceived notions about ethnic identities. It has the position of a partial witness. Taking a Sinhala or Tamil stand, we move then in an interpretative circle that we cannot do much about in this very case; we have only four short lines, 48 legible akșaras, and little comparative textual and historical material that makes it very difficult, but not impossible, to break away from pre-determined interpretative models.

We now understand why the statue and the inscription are so important. It is not their religious significance per se that is important in the present debate initiated by the famous Sinhala archaeologist and historian S Paranavitana (Paranavitana 1983: 80.) followed by others in his spirit (Hettiaratchi 1988: $139-140^{27}$ and revived in 1984 by Cyril Mathew and Sirisoma, and in 1991 by the late President R. Premadasa (Sunday Observer 1991: January 20. Daily News 1991: February 2) ${ }^{28}$, but their being capable of rationalising political aims. For us of course, the study of the religious significance per se, in its historical setting, of the statue and the inscription, is important enough.

\section{References}

\section{Anon}

1994 His Spirit Sways Present Politics. Island International May 4, 1994: 14.

Boisselier Jean et al.

1978 The Image of the Buddha. General ed. David L. Snellgrove. London: Serindia Publications.

\section{Cāttañār}

1981 Maṇimekalai. Cennnai: Ṭakțar U. Vē. Cāmainataiyar nūlnilaiyam. [1898]

Ceylon Antiquary

1916-17 The Ceylon Antiquary; vol. 2, pt 2.

Coomarswamy, Ananada $K$.

1980 The Origin of the Buddha Image. New Delhi: Munshiram Manoharlal. [1972]

\footnotetext{
${ }^{27}$ This Sinhala scholar, S. B. Hettiarratchi, says that many parts of the north and the north-eastern provinces appear to have been populated during the early part of the Anurādhapura period (and that the first Tamil settlements were in the 10th century). To support this he refers to among other sources the Vallipuram inscription that speaks of Badakara. It is, according to this scholar, presumably identical with modern Vallipuram near point Pedro. E T Kannangara has also paved the way for a political interpretation. He states that ruins of a Buddhist Vihāra, foundations of buildings, old bricks, and damaged images of the Buddha were found in Vallipuram. These finds evidently prove that this village was in the past a Sinhala settlement. See Kannangara 1984.

${ }^{28}$ For his political concept on Buddhism see Schalk 1990a.
} 
Cīlavamsa

1980 Cūlavamsa, Being the More Recent Part of the Mahāvamsa. 2 vols. London: Pali Text Society. [1925]

Daily News

1991 The Daily News. Colombo.

Dharmadasa, K. N. O.

1994 A Note on the Linguistic Aspect of Peter Schalk's Paper. Serendipity 3: $88-90$.

Elizarenkova, T. IA.

1972 Influence of Dravidian Phonological System on Sinhalese. International Journal of Dravidian Linguistics 1: 126-137.

Fausbøll, V. [Ed.]

1963 Jataka together with its Commentary Being the Tales of the Anterior Births of Gotama Buddha. London: Pali Text Society.

Gunawardana, R. A. L. H.

1979 Robe and Plough. Monasticism and Economic Interest in Early Medieval Sri Lanka. Tucson: University of Arizona Press.

Härtel, J. A. H.

1971 Propyläen Kunstgeschichte. Indien und Südostasien. Berlin: Propyläen Verlag Berlin.

Hettiaratchi, S. B.

1988 Social and Cultural History of Ancient Sri Lanka. Delhi: Sri Satguru Publications.

Hinüiber, Oskar v.

1986 Das ältere Mittelindisch im Überblick. Wien: Verlag der Österreichischen Akademie der Wissenschaften. (Österreichische Akademie der Wissenschaften. Phil.- Hist. Klasse. Sitzungsberichte, 467)

Jayaweera, Neville

1991 Sri Lanka Tow ards a Multi-Ethnic Democracy? Oslo: PRIO.

Kannangara, E. T.

1984 Jaffna and the Sinhala Heritage. Homagama: E. T. Kannangara.

Karunaratne, $\mathbf{S}$.

1984 Epigraphia Zeylanica 7. Colombo: Archaeological Survey of Ceylon.

Mahāuamsa

1958 The Mahāvamsa. London: Pali Text Society. [1908]

Mathew, Caluwadewage Cyril

1983 Sri Lanka. An Appeal to UNESCO to Safeguard and Preserve the Cultural Property in Sri Lanka Endangered by Racial Prejudice, Unlaw ful Occupation or Wilful Destruction. Colombo: C. C Mathew. [microform]

Nāgacāmi, Irā

1994 Nākattivu eṇnum ịlam. Cenñai; pp. 220-222. [Tamiln]

Obeyesekere, Gananath

1970 Religious Symbolism and Political Change in Ceylon. Modern Ceylon Studies 1: 50-51.

Paranavitana, Senarat

1936 Vallipuram Gold Plate Inscription of the Reign of Vasabha. Epigraphia Zeylanica 4: 228-237. 
1983 Vallipuram Gold Sheet Inscription. In: Inscriptions of Ceylon; vol. 2, pt 1: Late Brahmi Inscriptions; pp. 79-81. Colombo: Archaeological Survey of Ceylon.

Pieris, P. E.

1917 Nagadipa and Buddhist Remains in Jaffna. Journal of the Royal Asiatic Society, Ceylon Branch 70, 26: 11-44.

\section{Ragupathy, Ponnampalam}

1987 Early Settlements in Jaffna. An Archaeological Survey. Madras: Thillimalar Ragupathy.

Schalk, Peter

1988a Cinkala Pautta Iṇaveṛi Tìviravātam. Cennnai: Poṇnịi.

1988b 'Unity' and 'Sovereignty'. Key Concepts of Militant Buddhist Organization in the Present Conflict in Sri Lanka. Temenos 24: 55-87.

1990a The Concept of Concord in President Ransinghe Premadasa's Buddhist-Political Discourse. Lanka 4: 22-92.

1990b The Lankan Mahasangha's Concept of a Dharmacracy and Society. In: Radical Conservatism. Buddhism in the Contemporary World. Articles in Honour of Bhikkhu Buddhadasa's $84^{\text {th }}$ Birthday Anniversary; pp. 354-359. Bangkok: Thai Inter-religious Commission for Development. International Network of Engaged Buddhists.

1993 Review of Stanley Jeyaraja Tambiah, Buddhism Betrayed? Religion, Politics, and Violence in Sri Lanka. Chicago, 1992. Temenos 29: 183189.

1994a The Vallipuram Image - Again. Serendipity, 2, 1 (1994), pp. 41-49.

1994b Reply to Chandra R. de Silva. Serendipity 3/1: 85.

1994c Reply to K. O. N. Dharmadasa. Serendipity 3/1: 90.

1994d Second Reply to K. N. O. Dharmadasa. Serendipity 4/1 90-91.

Silva, C. R. de.

1994 Vallipuram Buddha Image - Again. Serendipity 3/1: 84-85.

Sunday Observer

1991 Sunday Observer. Colombo.

\section{Tambiah, Stanley Jeyaraja}

1992 Buddhism Betrayed? Religion, Politics, and Violence in Sri Lanka. Chicago: University of Chicago Press.

Veluppillai, A.

1979-80 Tamil Influence in Ancient Sri Lanka with Special Reference to Early Brahmi Inscriptions. Journal of Tamil Studies 16-17: 6-19.

1980 Epigraphical Evidences for Tamil Studies. Cennai: Ulakat Tamilaraycci Niruvanam. (International Institute of Tamil Studies, 24)

1981 Tamil in Ancient Jaffna and Vallipuram Gold Plate. Journal of Tami! Studies 19: 1-14.

1990 Religions in Yālppannam up to the Thirteenth Century. Lanka 5: 10-42.

Forthc. History of Tamil Buddhism in Ilankkai. In: Peter Schalk (ed.), Buddhism among Tamilar. Uppsala: Uppsala University.

Vogel, J.

1929-30 Prakrit Inscriptions from a Buddhist Site at Nagarjunikonda. Epigraphia Indica 20: 22. 